\title{
Ulotny wiersz okolicznościowy Leszka Kołakowskiego z 1973 roku
}

Janusz Maciejewski 
NAPIS Seria VI 2000

\author{
Janusz Maciejewski
}

\title{
Ulotny wiersz okolicznościowy Leszka Kołakowskiego z 1973 roku
}

$\mathrm{P}$ odany przez mnie niżej do druku, niepublikowany dotąd, drobny tekst Leszka Kołakowskiego ma dość skomplikowaną historię, tak ze względu na swoją genezę, jak i na obieg czytelniczy i rodzaj funkcjonowania w świadomości społecznej. Należy do dużej grupy żartobliwych utworów okolicznościowych, jakimi wielki filozof, a zarazem dobry poeta, hojnie obdziela przyjaciół, znajomych czy niektóre sympatyczne sobie imprezy (należą do nich na przykład wiersze jubileuszowe). O wiersze te autor nie dba, nie zbiera ich, nie publikuje. Krążą samodzielnie w niektórych środowiskach bądź spoczywają u adresatów.

Wiersz tu publikowany należy do nich, ale zarazem różni się od pozostałych, bo nie wywołała go żadna konkretna okoliczność, choć zarazem jest typowym właśnie okolicznościowym wierszem politycznym. Historia jego była następująca.

$\mathrm{Na}$ początku lat siedemdziesiątych przygotowywałem dla serii „Biblioteka Narodowa” wydawnictwa Ossolineum nową edycję Literatury barskiej, mającą zastąpić tom Poezji barskiej Kazimierza Kolbuszewskiego z 1928 roku (BN I 108). Kolejne etapy pracy nad tą publikacją referowałem sukcesywnie na zebraniach Pracowni Literatury Oświecenia Instytutu Badań Literackich Polskiej Akademii Nauk. W zebraniach tych brał także udział nieżyjący już historyk idei Henryk Hinz (autor między innymi prac o filozofii i historiozofii Hugona Kołłątaja), dobry znajomy Leszka Kołakowskiego. Poprosił mnie wówczas o maszynopisy kilku cytowanych przez mnie bardziej "smakowitych” wierszy politycznych z czasów konfederacji 1768 roku, a następnie przesłał przebywającemu juz wtedy na emigracji i wykładającemu w Oksfordzie Leszkowi Kołakowskiemu. Ten z kolei odpowiedział świetną stylizacją — właśnie poniżej ogłaszaną — której jeden z odpisów Hinz przekazał także mnie.

Lament krześcijanina nad zepsuciem świata doczesnego znakomicie imituje język i oddaje mentalność polskiego szlachcica XVIII stulecia. Ale zarazem jest utworem o wydarzeniach 
początku lat siedemdziesiątych XX wieku. Wśród postaci i wydarzeń „opłakiwanych” w wierszu jest bowiem prezydent Stanów Zjednoczonych Richard Nixon i pogłosy afery Watergate, jest kolejna wojna izraelsko-arabska, konflikt radziecko-chiński, początek polityki détente ze strony Francji i Wielkiej Brytanii wobec Związku Radzieckiego, wreszcie gospodarcza i polityczna zależność gierkowskiej PRL od Moskwy. Wyrażenie tych problemów i realiów poprzez język sarmackiego szlachcica XVIII wieku rodzi dodatkowy efekt komiczny, wzbogacający odbiór utworu.

Dlatego też wiersz ten sprawiał dużą radość czytającym go przedstawicielom środowisk polonistyczno-historyczno-filozoficznych Warszawy, Krakowa, Wrocławia, Poznania czy Łodzi, wśród których krażył od schyłku 1973 roku. Sam czytałem go wśród salw śmiechu i oklasków w redakcji „Tekstów”, na zebraniu Pracowni Literatury Oświecenia IBL PAN we Wrocławiu, gronu przyjaciół na łódzkiej polonistyce (gdzie prowadziłem wówczas zajęcia zlecone) i na wielu spotkaniach towarzyskich.

Choć środowisko, w którym utwór egzystował, należało do ówczesnych elit intelektualnych, sposób istnienia i obieg Lamentu był zbliżony do folkloru, realizował się w bezpośrednich kontaktach międzyludzkich (gdzie indziej określiłem podobne zjawiska jako „folklor środowiskowy"). Nie przeszedł bowiem przez druk, tekst jego byl powielany ręcznie bądź na maszynie, często był czytany głośno — zatem nie tylko tematyka i sposób ujęcia, ale i obieg tekstu wśród odbiorców kwalifikował go do okolicznościowej literatury politycznej. W stosunku jednak do innych jej przejawów z czasów komunizmu (typu utworów „marcowych” 1968, „grudniowych” 1970, „sierpniowych” 1980) był znacznie bardziej wyrafinowany literacko, z niebanalnymi odwołaniami intelektualnymi, którymi wpisywał się też w staropolskie tradycje tego typu. Dodały one Lamentowi krzésijanina blasku, którego i dzisiaj jeszcze, kiedy wydarzenia początku lat siedemdziesiątych już dawno przestały być aktualne, nie starł czas, tak na ogół okrutny dla tekstów wywołanych okolicznościami życia społecznego. 


\section{Leszek Kołakowski}

\section{Lament krześcijanina nad zepsuciem świata doczesnego}

Panie Jezu słodki, co się tutaj dzieje,

Gdzie ino popatrzeć - kurwy a złodzieje!

Król, co w Ameryce rządy swe sprawuje,

Dokumenta ważne niezbożnie fałszuje.

Żyd z Saracenami za bary się biorąc

Wojennego ognia rozpalili gorąc,

Za nic sobie cnoty i zbawienie mając,

Wdowy i sieroty biedne uciskając.

Ludem krześcijańskim wszędy tyran włada,

Utrapienie srogie na każdego spada.

Gdzie oczy obrócisz, jakiś Herod zbrodzień

Rzezie niewiniątek szykuje ci co dzień.

Ruski car, na stolcu najwysokszym siadłszy,

Gdzie by ludek prosty gnębić ino patrzy,

I tylko potrząsa okrutnym nahajcem,

Lecz się boi zmierzyć z niewiernym Kitajcem.

Francuz bez sumnienia zasię i bez cześci

To z Moskalem, to się znów z Kitajcem pieści.

Angliczanin złodziej też nie lepszy prawie:

"Za talara - mówi - stanę w twojej sprawie".

O świadku niegodny, któren mówisz „daj no”,

Przykazania boskie już ci są za łajno?

Pokarze cię Pan Bóg, ladacznico sprośna,

Nierychliwa ręka Jego, aleć mocna!

Jezu Nazareński, który cirzpisz męki,

Użyj na bezbożnych sprawiedliwej ręki!

Lechita waleczny, nawet on - o wstydzie! -

Żwawo za czartowskim pokuszeniem idzie.

Ojczyznę i przodków mając chwałę za nic,

Bez szemrania nosi moskiewski kaganiec,

Nagrody ni kary niepomny wieczystej, 
Tylko zażyć chciałby uciechy nieczystej.

Zapomniawszy całkiem prawości szlacheckiej,

Też do uczty rwie się w jaskini zbójeckiej.

Takeśmy się stali jako stado zwierząt,

Wszystko, co uświadczysz, to ucisk a nierząd.

Prostaczkom się przypatrz albo i wielmożom:

Wszyscy bluźnią, kradną, łżą i cudzołożą,

A kto na tyrana idzie miecz gotować,

To pewnikiem warchol, co chce sam królować.

A człowiek podściwy na obojgu przegra,

Aż rząd na świat przyjdzie Japońca i Negra.

Że w Antykrystowym więc żywiemy czasie, Jużcić ku końcowi świat niechybnie ma się.

Sporzadzit Lesco Colacovius,

dan 1 listopada, w dzień Wszystkich Świętych A. D. 1973 $w$ Oxonium 